\title{
MRS Seeks Nominees for Outstanding Young Investigator Award, 1998
}

The Materials Research Society is accepting nominations for the Outstanding Young Investigator Award to be announced at the 1998 MRS Spring Meeting in San Francisco. The award is intended to recognize outstanding, interdisciplinary scientific work in materials research by a young scientist or engineer. The award recipient must also show exceptional promise as a developing leader in the materials area.

The award consists of a $\$ 3,000$ cash prize, a presentation trophy bearing a brief citation, and a certificate. Reasonable travel expenses to attend the Spring Meeting at which the award is presented and the meeting registration fees will be reimbursed.

Previous recipients are Stuart S.P. Parkin (IBM) for contributions in new materials, high $\mathrm{T}_{\mathrm{c}}$ superconductors, and magnetic multilayers displaying oscillatory exchange coupling; David D. Awschalom (University of California-Santa Barbara) for contributions to the field of nanostructured materials; Charles M. Lieber (Harvard University) for contributions to the understanding of novel materials through synthesis and elegant determination of complex local structure and electronic properties; David J. Eaglesham (AT\&T Bell Laboratories) for creativity, leadership, and experimental ingenuity in discovery and understanding of fundamental interface, surface, and defect phenomena in semiconductor crystal growth; A. Paul Alivisatos (University of California-Berkeley) for leadership in materials research, notably in the field of nanocrystals; Antonios G. Mikos (Rice University) for the synthesis and process- ing of new biomaterials for tissue engineering, supports for cells, tissue-growth conduits, targeted cell-adhesion substrates, and cellular-response stimulants; and Christopher N. Bowman (University of Colorado) for seminal contributions to the field of highly crosslinked polymers, information storage materials, and computational methods in polymerization engineering (an article on Bowman's presentation is scheduled to appear in a future issue of MRS Bulletin).

The deadline for submission of nominations is October 1, 1997. For guidelines and application forms, contact John B. Ballance, Executive Director, Materials Research Society, 9800 McKnight Road, Pittsburgh, PA 15237; phone (412) 367. 3003; fax (412) 367-4373; e-mail: ballance@ mrs.org.

1998 MRS SPRING MEETING San Francisco, CA April 13 - April 17

Meeting Chairs: John A. Emerson, Sandia National Laboratories; Ronald Gibala, University of Michigan; Caroline A. Ross, Massachusetts Institute of Technology; Leo J. Schowalter, Rensselaer Polytechnic Institute

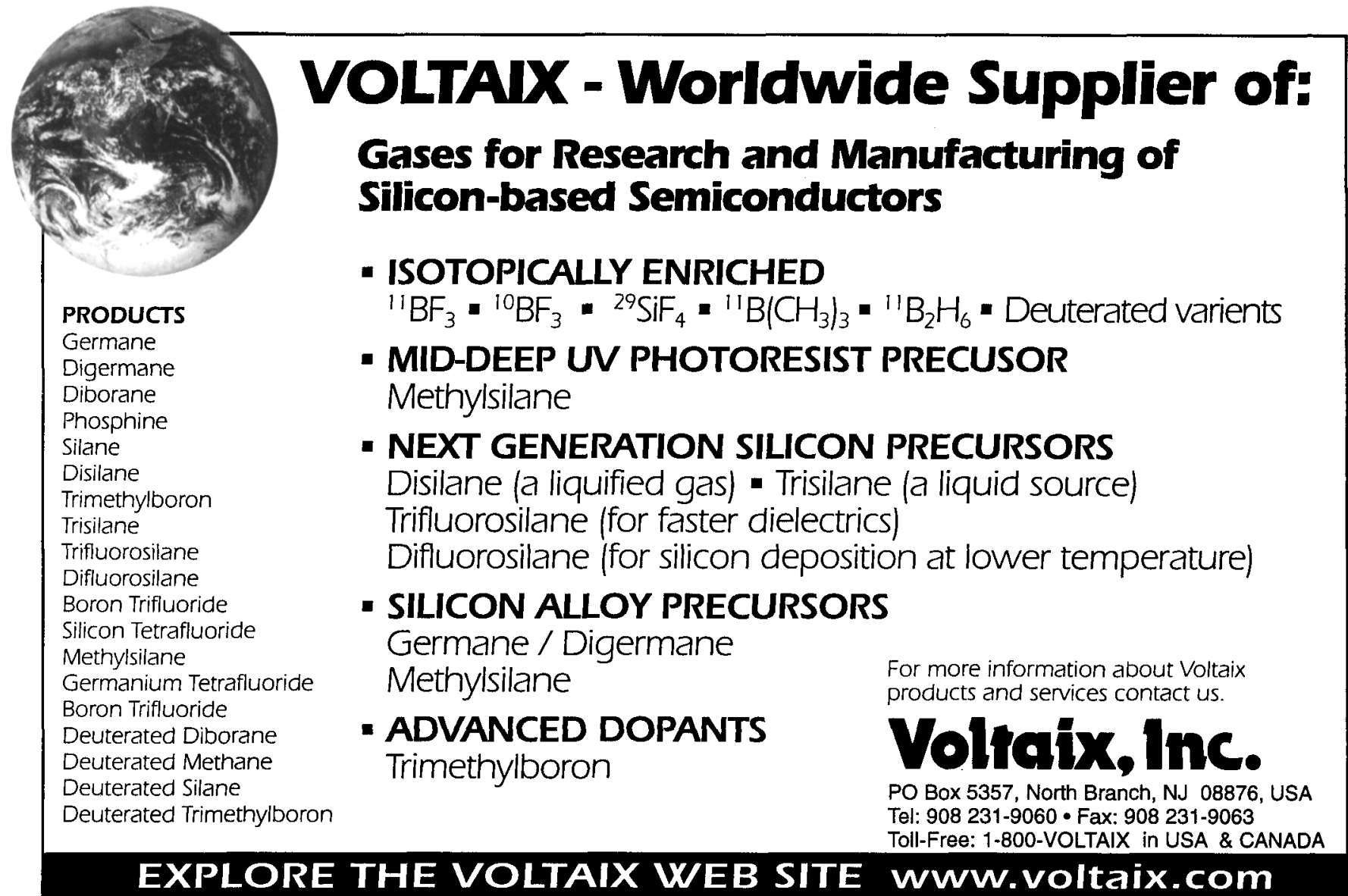

Circle No. 13 on Reader Service Card. 